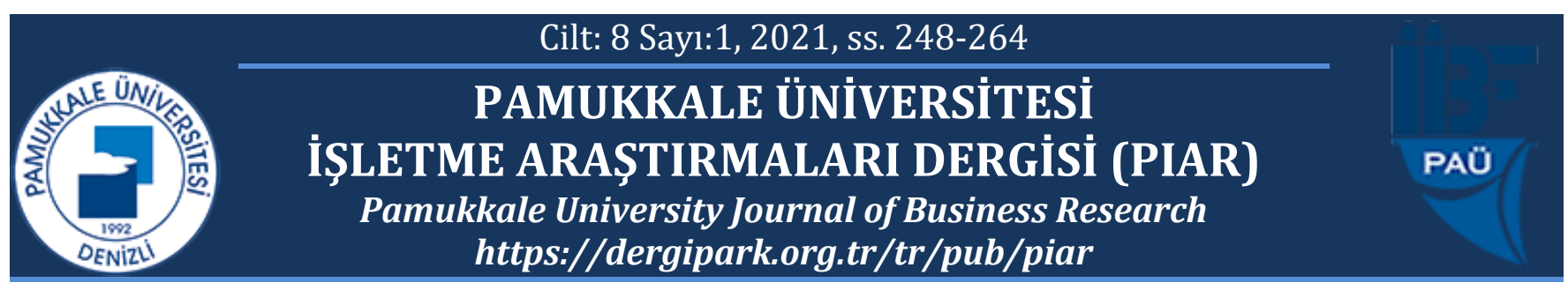

\title{
Bilim, Teknoloji ve Kadın: Çalışmanın Geleceğine Dair Bir Değerlendirme
}

Science, Technology and Women: An Assessment of the Future of Work

Gözde TOPRAKCI ALP ${ }^{1 *}$

\section{Beyhan AKSOY²}

\begin{abstract}
1Akdeniz Üniversitesi, Çalışma Ekonomisi ve Endüstri İlişkileri, toprakcigoz@gmail.com, https://orcid.org/0000-00021689-2707

${ }^{2}$ Akdeniz Üniversitesi, Çalışma Ekonomisi ve Endüstri İlişkileri, beyhanaksoy@akdeniz.edu.tr, https://orcid.org/00000001-6365-8131

* Yazış1lan Yazar/Corresponding author
\end{abstract}

Makale Geliş/Received: 03.05.2021

Makale Kabul/Accepted: 10.06.2021

\section{Öz}

Dünya genelinde çalşma ve istihdam biçimleri sürekli değişmekte, yeni teknolojiler ve özellikle bilgi teknolojileri işgücü piyasasının geleceğini yakından etkilemektedir. Teknolojik gelişmelerin, kadın işgücü üzerindeki etkisi ise çalışma yaşamındaki mevcut eşitsizlikler dikkate alnndiğında önemli bir konu olarak gündeme gelmektedir. Bu çalısmada teknolojik gelişmelerin kadınlar üzerindeki etkisini analiz etmek, Fen, Teknoloji, Mühendislik ve Matematik (FETEMM) alanlarında kadınların görünürlüğünü tartışmak ve bu alandaki cinsiyet eşitsizliğini ortadan kaldırmak için politika önerileri geliştirmek amaçlanmıştır. Teknoloji odaklı çalışmada kadınların yetersiz temsiliyetleri kaynağıı teknoloji ve cinsiyetlere dayah kalı yargılardan almaktadır. Çalışmada kadın istihdamında toplumsal cinsiyet kalip yargilarn üzerinden hareket edilerek, devletin, özel sektörün ve sivil toplumun bu konuda yapabileceklerine dair önerilere yer verilmiştir.

Anahtar kelimeler: Kadın, Teknoloji, İstihdam, Toplumsal Cinsiyet, FETEMM.

JEL kodlari: J16, J21.

\begin{abstract}
Work and employment forms are constantly changing around the world, and new technologies and especially information technologies closely affect the future of the labor market. Considering the current inequalities in working life, the effect of technological developments on women workforce comes to the fore as an important issue. In this study, it is aimed to analyze the effects of technological developments on women, to discuss the visibility of women in Science, Technology, Engineering and Mathematics (STEM) fields and to develop policy recommendations to eliminate gender inequality in this field. Under-representation of women in technologyoriented work derives from stereotypes based on technology and gender. This study includes suggestions on what the state, private sector and civil society can do on this issue, based on gender stereotypes in women's employment.
\end{abstract}

Keywords: Woman, Technology, Employment, Gender, STEM.

JEL codes: J16, J21. 


\section{GİRIŞ̧}

Sosyal, teknolojik ve endüstriyel değişimler sonucunda günümüzde daha çok sayıda kadın çalışma hayatında yer almaya başlamıştır. Bilgi teknolojilerindeki gelişmeler, bilgiye ulaşma ve eğitime erişimi kolaylaştırarak kadınların çalışma hayatına katılımını daha fazla mümkün kılsa da (Atalay ve Varol, 2016) cinsiyet eşitsizlikleri çalışma yaşamındaki önemli sorunlardan biri olmaya devam etmektedir. Erkeklerin işgücü piyasalarına katılma eğilimi daha yüksek olsa da kadınların işgücüne katılımındaki artış, dikkat çekici ekonomik gelişmelerden biridir (Ortiz-Ospina vd., 2018). Bununla birlikte kadınların çalışma yaşamına katılımında cinsiyet eşitliğini savunan görüşler (Özçatal, 2011; Toksöz ve Memiş 2018), kültürel ve sosyal normların, kadınların ekonomik potansiyellerini tam olarak gerçekleştirmelerini engelleyerek fiziksel ve ekonomik hareketliliklerini kısıtladıklarını savunmaktadır.

1980 sonrasında üretim sistemlerinde meydana gelen gelişmeler emek yoğun teknolojilerin önemini artırmış ve istihdamın yapısını dönüştürmüştür. Dünyanın pek çok yerinde uygulamaya konulan yapısal uyum ve istikrar politikaları ile kamu harcamalarının kısılması, özelleştirme uygulamaları, uluslararası rekabet için birim işgücü maliyetlerinin düşürülmesi ve işgücü piyasalarında kuralsızlaşmanın yaygınlaşması yeni dönemin özelliklerinden bazılarıdır (KEİG, 2015). Yüksek vasıflı olmayan işlerde daha itaatkâr ve sendikalaşma eğilimi düşük kadınlara ve gençlere olan talebin artması da işgücüne kadınların katılımını etkileyen gelişmelerden bir diğeridir. Kadınlar işgücüne katıldıkça daha önceleri onlar tarafından yerine getirilen ev içi bakım emeği de başta göçmen kadınlar olmak üzere yine kadınlar tarafından yerine getirilmeye başlanmıştır (ILO, 2019b).

Kadın istihdamının bir diğer özelliği de bazı sektör ve mesleklerin erkeklere daha uygun olduğu yargısı ile kadınların bu alanlarda istihdam edilmeleri ve kariyerlerinde yükselmelerinin zor oluşudur. Kadınlar ve erkekler için toplumda farklı roller ve sorumlulukların benimsenmesi cinsiyete dayalı işbölümü olarak tanımlanmaktadır. Cinsiyete dayalı işbölümü hem ekonomik yönleri hem de cinsiyet kimliklerinin sosyal inşası bakımından toplumsal cinsiyet eşitsizliğinin temel bir özelliğidir (Cohen, 2004). Cinsiyete dayalı iş bölümüne göre hemşirelik, öğretmenlik, sekreterlik, psikologluk, diyetisyenlik gibi meslekler kadın işi olmaya ve böyle algılanmaya; şoförlük, mühendislik, pilotluk, teknikerlik ve müteahhitlik gibi meslekler de erkek işi olmaya ve bu şekilde algılanmaya devam etmektedir (Ecevit Satı ve Oktay Yılmaz, 2019: 55).

Hem kadınlar hem de erkekler gelişen teknolojiler ve otomasyonun da etkisiyle mevcut işlerini kaybetme riski altında olsalar da kadınların yaptıkları işlerde bu risk daha yüksektir. Bu risk çoğunlukla erkeklerin sahip olduğu işlerde yaklaşı \%20 iken, çoğunlukla kadınların yaptığı işlerde \%50 civarındadır (McKinsey, 2019). Toplumsal cinsiyet eşitsizliği kadınların çalışma yaşamındaki dezavantajlı konumlarını belirleyen en önemli etkendir. Teknoloji temelli sektörlerde ve işlerde kadınların daha fazla yer alması, bahsedilen bu dezavantajlı konumun üstesinden gelmenin bir yolu olarak görünmektedir.

Kadınların çoğunlukta olduğu sektörlerde, düşük ücretler teknolojik yeniliğe yatırımı baskılayabilecek sonuçlar doğurabilmektedir. Toplumsal cinsiyete dayalı işbölümü işgücü maliyeti yoluyla çeşitli şekillerde teknolojik gelişmeyle etkileşime girmektedir. Çoğunlukla kadınlardan oluşan, düşük maliyetli ve sendikasız bir işgücü söz konusu olduğunda, 
firmaların otomasyona yatırım yapma olasılıkları çok daha düşüktür (Howcroft ve Ruber, 2019).

Birçok araştırma göstermektedir ki FeTeMM alanlarında kadın uzmanların eksikliği kadınların bilişsel becerilerindeki ${ }^{a}$ eksiklikten değil, kadınların bu alanlardan dışlanmasına yol açan başta FETEMM eğitimi alanlarındaki erkek egemen anlayıştan kaynaklanmaktadır (Taş ve Bozkurt, 2019). Cinsiyet eşitliği olan bir toplumsal düzen kurmak adına hem üretken ekonomiyi hem de toplumsal yeniden üretim sistemini kadınlar lehine dönüştürmek için bir dizi eylem ve politika yaklaşımı gerekmektedir. Bu çalışmanın odak noktası, teknolojik gelişimin kadınlar üzerindeki etkisini ve Fen, Teknoloji, Mühendislik ve Matematik (FETEMM/STEM) alanlarında kadınların temsiliyetlerini değerlendirmektir. Türkiye'de FeTeMM eğitim seviyesi ve uzmanlığına göre cinsiyet dağılımında önemli eşitsizlikler söz konusudur. Buna bağlı olarak hem Bilgi Teknolojileri (BT) hem de FeTeMM alanlarında kadın istihdamı düşük seyretmektedir. Bu çalışmada FETEMM alanlarında kadınların yetersiz temsiliyetine yol açan kalıp yargılar ele alınmaktadır.

FeTeMM alanlarındaki eşitsizlik en temelde toplumsal cinsiyet eşitsizliğinden kaynaklanmakta ve bu alanlardaki eşitsizliği gidermek için birçok aktörle eş zamanlı çalışma yapılması gerekmektedir. Bu doğrultuda bu çalışmada dünyada ve Türkiye'de kadınların teknoloji temelli işlerde yer almasının önündeki engeller açıklanacak ve devletin, özel sektörün ve sivil toplumun bu konuda yapabileceklerine dair genel bir çerçeve çizilecektir.

\section{TEKNOLOJI VE KADIN İSTİHDAMI}

Üretimde post-fordist süreç olarak tanımlanan dönüşümle, kadın işgücü açısından da yeni bir dönem başlamıştır. Teknolojik gelişmeler, sanayide beden gücüne olan ihtiyacı azaltarak kadınların ücretli işgücü piyasası içinde öncekine kıyasla daha kolay yer almasını sağlamış ve kadının işgücü piyasasındaki varlığı daha meşru bir zemine taşınmıştır (Atalay ve Varol, 2016). Bilgi teknolojilerindeki gelişmelerin kadın işgücüne olumlu etkileri yanında olumsuz etkileri de söz konusudur. Bir işin statüsü ve beceri gerekleri dijitalleşmeyle ilişkili olarak arttığında o iş için erkekleri tercih etme eğiliminin artması, bu işlerde kadın çalışan sayısının erkeklere göre az olması ile açıklanmaktadır. Cinsiyetler arasındaki bu fark, bu işlerdeki yönetici pozisyonları için de doğal olarak aynı şekildedir. Bu duruma yol açan temel nedenlerin başında erkeklerin FeTeMM alanlarında eğitim almaya daha çok teşvik edilmesi gelmektedir. Bir diğer neden de kadınların kendilerine rol model alabilecekleri kadın sayısının az oluşudur.

Teknoloji ile ilişkili işleri eril olarak görenlerin dayanaklarından bir diğeri de kimliktir. Kimlik, erillik ve teknoloji arasındaki ilişki içerisinde önemli bir mekanizma olarak ortaya çıkmaktadır. Dolayısıyla kadınların teknoloji alanlarındaki sınırlı varlıkları onların dişil kimliği ile açıklanmaktadır. Dişil ve eril kimliğe yönelik önyargılardan biri kadın ve erkeğin teknik yeterlilikleri arasındaki farklılıklardır. Teknoloji daha çok güç gerektiren ve erkeğe ait bir alan olarak görülmektedir. Dolayısıyla toplum ve teknoloji ilişkisinde ortaya çıkan

\footnotetext{
a Bilişsel beceriler, akademik konuları başarıyla öğrenmek için ihtiyaç duyulan zihinsel yeteneklerdir. Temel bilişsel beceriler, dikkat, odaklanma, depolama, ayrıştırma ve kaynaştırma olarak; ileri düzey bilişsel beceriler ise karar verme, işlemleme hızı, problem çözme, duygu regülasyonu, akıl ve mantık yürütme şeklinde sınıflandırılmaktadır.
} 
gerçek, toplumun ataerkil doğasından yansıyan teknolojinin ataerkil doğasıdır (Savcı, 1999). Kadınların teknoloji temelli işlerde erkeklere kıyasla geride kalmalarının bir diğer nedeni de bu alandaki işlerde mesai saati kavramının olmamasıdır. Ev içi sorumluluklar göz önünde bulundurulduğunda, belirsiz mesai kadınlar için zorlayıcı bir koşul olmakta ve bu alanlarda çalışma fikri genellikle kadınlar için erkeklere olduğu kadar cazip gelmemektedir. Dolayısıyla kadın işgücü, imalat sektöründen olduğu gibi teknoloji sektöründen de dışlanmakta ve yazılım alanından ziyade veri girişi ve çağrı merkezi gibi yaratıcılıktan uzak işlerde istihdam edilmektedirler (Aksoy, 2012).

Kadın işgücü vasıfsız sayılan işlerde yoğunlaşırken, çoğunluğunu kadınların yaptığı işler erkeklerin hakimiyetinde olanlara göre görece daha az vasıflı olarak görülmektedir (Adam vd., 2006). Teknoloji ise, risk katsayısı yüksek alanlardan biri olarak görülmekte ve riskli görülen alanlarda erkeklere daha fazla güven duyulmaktadır. Bilgi ve iletişim teknolojilerinin kullanımında küçük-büyük işletmeler arasındaki eşitsizliğin yanı sıra kadınerkek, yaşlı-genç, eğitimli-eğitimsiz bireyler arasında da büyük farklılıklar bulunmaktadır. Türkiye' de ise kadın ve erkek arasında bilgi ve iletişim teknolojileri kullanımındaki eşitsizlik yüksektir (Deloitte, 2018).

Öktem Özgür ve Seçer (2017) çalışmalarında kadınların bilgi ve iletişim teknolojileri açısından ayrımcılık deneyimi yaşadıkları sonucuna ulaşmışlardır. Söz konusu deneyimin nedenleri ise, işin ve işyerinin özellikleri, kadınların erkeklere göre daha geri planda kalmaları, toplumsal cinsiyet rollerinden dolayı kadına atfedilen rolleri, kadın ve erkeklerin yaratılış olarak farklı doğalara sahip olmaları ve son olarak da bilgi ve iletişim teknolojileri ile ilgili beceri yetersizliği ile açıklanmıştır.

Kadınların teknoloji alanlarındaki yetersiz temsiliyetlerini büyük teknoloji şirketlerinin kadın işgücü oranlarında da görmek mümkündür. Kadınlar Netflix'te toplam işgücünün \%47'sini, Amazon'da \%40'ın1, Twitter ve Uber'de \%38'ini, Facebook'ta \%36'sinı, Apple'da $\% 32$ 'sini, Google'da \%31'ini ve Microsoft'da \%27'sini oluşturmaktadır. Kadınların popüler teknoloji şirketlerinde yönetici, üst düzey ve yönetim pozisyonlarında da temsiliyetleri düşüktür (Richter, 2020).

Harvey Nash (2014) araştırmasına göre ABD'deki kadınlar CEO pozisyonlarının \%11'ine kadar yükselebilmektedirler. Ayrıca kadınlar S\&P 500 şirketlerindeki tüm CEO'ların sadece \%4'ünü oluşturmaktadır. Bu bulgular, 20 kadından sadece 5'inin teknoloji ile ilgili firmalarda (HP, IBM, Yahoo, Oracle ve Xerox) yer aldığını göstermektedir. Cinsiyet açısından teknolojik mesleklerin kıyaslamasında, kadınlar için en üst pozisyonda "Proje Yöneticisi" ve erkekler için en üst konum olarak "Yazılım Mühendisi" yer almaktadır (Ulusal Kadın ve Bilgi Teknolojileri Merkezi Raporu, 2016).

Deloitte Türkiye ve Türkiye Bilişim Sanayicileri Derneği'nin yapmış olduğu “Teknoloji Sektöründe Kadın" araştırmasına göre (2018), araştırmaya katılan ve teknoloji sektöründe çalışan kadınların \%19'u bilgi teknolojileri, \%13'ü de ar-ge/ürün geliştirme gibi çekirdek işlerde çalışmaktadır. Kadın çalışanların teknoloji sektörünü tercih etme sebepleri arasında gelecek vaat eden, gelişme fırsatlarına açık, dinamik ve sürekli değişken ve uluslararası uygulanabilirliği yüksek bir sektör olması yer almaktadır. Çalışma sonuçlarına göre teknoloji sektöründe kadın yöneticilerin sayısının erkeklere göre az olmasının nedenleri arasında; sektörün liderlik pozisyonları için erkeklere daha meyilli olması, teknoloji sektörünün erkek 
egemen bir sektör olması ve kadınların yönetimden yeterince destek görmemesi yer almaktadır (Deloitte, 2018).

PwC (Price Waterhouse Coopers) İngiltere'nin (UK) yapmış olduğu “Teknolojide Kadınlar ve Toplumsal Cinsiyet Farkını Kapatma Zamanı" araştırma raporuna göre (2017), kız çocuklarının okul eğitimlerinde FeTeMM dersleri alma olasılığı daha düşüktür ve bu fark üniversiteye kadar devam etmektedir. Kadınlar bir kariyer hedefi olarak teknolojiyi erkeklerden daha az olasılıkla düşünmektedirler ve yeterince kadın rol model de yoktur (PwC UK, 2017).

Dünya Ekonomik Forumu'nun 2016 araştırmasına göre, bilgi ve iletişim teknolojileri istihdam verileri, tüm sektörlerin istihdam değerlerinin altında seyretmektedir. Bilgi ve iletişim teknolojileri sektöründe; kadın CEO oranı \%5, kadın yönetim kurulu üyeleri oranı \%19'dur. Bilgi ve iletişim teknolojileri sektöründe; üst düzey rollere (kıdemli roller) sahip kadın oranı 2015 yılında \%11, 2020 yılında \%20, orta düzey rollere sahip kadın oranı 2015 yılında \%21, 2020 yılında \%29, alt düzey rollere (k1demsiz roller) sahip kadın oranı 2015 yılında \%32, 2020 yılında \%34, hat rollere (üretim, satıs, satın alma vb. birincil faaliyetleri içeren roller) sahip kadın oranı 2015 yılında \%23, 2020 yılında \%32, destek rollere (insan kaynakları, muhasebe, halkla ilişkiler, hukuk vb. hat rollere yardımcı olan roller) sahip kadın oranı 2015 yılında \%33, 2020 yılında \%38'dir. Dolayısıyla bilgi ve iletişim teknolojileri sektöründe kadın işgücü, genel işgücü ortalamasının altında seyretmektedir. Bu kapsamda düşünüldüğünde tüm sektörler bazında kadın çalışan oranı \%30 iken, bilgi ve iletişim teknolojileri alanında kadın çalışan oranı \%24'tür. Tüm sektörler bazında kadınların aleyhine ücret farkı oranı \%32 iken, bilgi ve iletişim teknolojileri alanında bu fark \%25'dir (WEF, 2016: 124).

G7 ülkelerinde teknoloji sektöründe kadınların temsil oranlarını değerlendiren PwC Çalışma Hayatında Kadınlar Endeksi -2020'ye göre, teknoloji sektöründe çalışan kadın istihdam oranı $\% 30$ ve teknoloji, medya ve telekomünikasyon sektörlerinde yönetim kurulu üyesi kadınların oranı \%23'tür. Teknoloji sektöründeki cinsiyete dayalı ortalama ücret eşitsizliği \%18 ile tüm sektörlerdeki G7 ortalamasının üzerindedir (PwC, 2020).

Tablo 1. Teknoloji Ölçeğinde Kadınların Değerlendirilmesi 2018 (Türkiye ve Seçilmiş Bazı Ülkeler (OECD-AB) Arası Kıyaslama)

\begin{tabular}{|c|c|c|c|c|c|c|c|c|c|}
\hline Ülkeler & $\begin{array}{c}\text { Teknolojik } \\
\text { İşücü } \\
\text { (Bin kişi) }\end{array}$ & $\begin{array}{c}\text { Teknolojide } \\
\text { İsücü (\%) }\end{array}$ & $\begin{array}{c}\text { Kadın } \\
\text { Teknolojik } \\
\text { İsücü } \\
\text { (Bin kişi) }\end{array}$ & $\begin{array}{c}\text { Teknolojide } \\
\text { Kadınlar } \\
(\%)\end{array}$ & $\begin{array}{c}\text { Issücünde } \\
\text { Kadın ve } \\
\text { Teknolojide } \\
\text { Kadın } \\
\text { Farkı (\%) }\end{array}$ & $\begin{array}{c}\text { Kadın } \\
\text { FETEMM } \\
\text { Mezunlar1 } \\
(\%)\end{array}$ & $\begin{array}{c}\text { Teknolojide } \\
\text { Ortalama } \\
\text { Ücret }(£)\end{array}$ & $\begin{array}{c}\text { Teknolojide } \\
\text { Kadınlar } \\
\text { için } \\
\text { Ortalama } \\
\text { Ücret (£) }\end{array}$ & $\begin{array}{c}\text { Teknolojide } \\
\text { Cinsiyete } \\
\text { dayalı } \\
\text { Ücret } \\
\text { Eşitsizliği } \\
(\%)\end{array}$ \\
\hline Türkiye & 245.20 & $\% 0,80$ & 24.30 & $\% 9,91$ & $\%-21,64$ & $\% 37,11$ & 35,738 & 32,730 & $\% 8,42$ \\
\hline A.B.D & 6.049 .11 & $\% 3,80$ & 1488.64 & $\% 24,61$ & $\%-22,15$ & $\% 24,24$ & 69,768 & 61,492 & $\% 11,86$ \\
\hline İngiltere & 1.608 .20 & $\% 4,84$ & 260.60 & $\% 16,20$ & $\%-30,48$ & $\% 31,03$ & 41,986 & 34,933 & $\% 16,80$ \\
\hline Almanya & 1.541 .10 & $\% 3,58$ & 255.50 & $\% 16,58$ & $\%-29,77$ & $\% 21,26$ & 41,930 & 31,447 & $\% 25,00$ \\
\hline Japonya & 3.136 .35 & $\% 4,70$ & 404.87 & $\% 12,91$ & $\%-30,43$ & $\% 15,25$ & 35,353 & 24,053 & $\% 31,96$ \\
\hline
\end{tabular}




\begin{tabular}{|c|c|c|c|c|c|c|c|c|c|}
\hline Yunanistan & 51.20 & $\% 1,07$ & 6.50 & $\% 12,70$ & $\%-32,01$ & $\% 30,07$ & 22,401 & 16,711 & $\% 25,40$ \\
\hline Çekya & 180.90 & $\% 3,38$ & 20.20 & $\% 11,17$ & $\%-33,18$ & $\% 23,08$ & 30,066 & 20,295 & $\% 32,50$ \\
\hline
\end{tabular}

Kaynak: 2018 Teknolojide Kadın Endeksi/Honeypot

Honeypot'un (2018) 41 ülkede yapılan kadınların teknoloji ölçeğinde ülkelere göre değerlendirildiği araştırmaya göre, Türkiye'de teknolojide kadın işgücü \%9,91, genel işgücü ile teknolojideki işgücündeki kadın oranı farkı \%21,64, kadın FeTeMM mezunları \%37,11 ve teknoloji sektöründe cinsiyete dayalı ücret eşitsizliği $\% 8,42$ 'dir. Tabloya göre FeTeMM bölümlerinden mezun kız öğrenci oranında Türkiye birinci sırada yer almaktadır. Ancak FeTeMM mezunu kız öğrencilerin yüksek oranına rağmen Türkiye OECD ülkeleri arasında teknoloji alanında kadın istihdamında iyi bir performans sergilememektedir. Eğitimin tüm seviyelerinde kadınların okullaşma oranının artırılması, mesleki eğitimde kız çocuklarının teşvik edilmesi ve kadın işi-erkek işi ayrımına dair tutumların önüne geçilmesi kadın istihdamının artırılması noktasında önemlidir.

\section{KADINLAR VE İŞGÜCÜ PIYYASASININ GELECEĞİ}

Teknolojik ilerlemeler çalışma hayatının dijitalleşmesi ve otomasyonunu artırırken işgücü piyasasındaki kadınlar üzerinde de önemli sonuçlar doğurmaktadır. Çalışma hayatında dijitalleşmeye atfedilen değere rağmen, otomasyonun bir sonucu olarak yeni fırsatların yaratılması ve çalışma hayatında teknolojiye bağımlılığın cinsiyete olan etkisini vurgulamak konusunda sınırlı girişimde bulunulmuştur.

Türkiye' de kadınların istihdam oranı, erkeklerin oranının yarısından daha azdır. Hanehalkı işgücü araştırması sonuçlarına göre; 2019 yılında, Türkiye'de 15 ve daha yukarı yaştaki istihdam edilenlerin oranı $\% 45,7$ olup bu oran kadınlarda $\% 28,7$, erkeklerde ise $\% 63,1^{\prime}$ dir. İşgücüne katılma oranı Türkiye'de 15 ve daha yukarı yaştakiler için \%53 iken bu oran kadınlarda \%34,4, erkeklerde ise $\% 72$ 'dir. İsssizlik oranı ise Türkiye'de 15 ve daha yukarı yaştakiler için \%13,7, kadınlarda bu oran \%16,5, erkeklerde ise \%12,4'tür (TÜİK, 2019).

Emek süreci kavramı, kadın ve erkek arasındaki ayrıma bağlı olarak mesleklerin toplumsal cinsiyet yanlı sınıflandırılmasına dikkat çekmektedir. Madencilik, metal işleri, diğer vasıflı imalat işleri, teknik vasıf gerektiren vb. işler erkek işi olarak görülürken sekreterlik, hemşirelik, öğretmenlik, bakım, temizlik ve yemek vb. işler ise kadın işi olarak görülmektedir. Bu işlere kadınların yatkınlığı, duygusallık ve sabırlılık gibi kadınların doğalarında var olduğu düşünülen özelliklerle açıklanmaktadır. Bu tür bir görüş kadınları erkeğin egemenliğindeki teknoloji alanından uzakta tutmaktadır (Savc1, 1999).

Günümüzde otomasyon yapay zekâ, makine öğrenimi ve akıllı yazılımlar, sanal asistanlık ve sanal sağlık hizmetlerine kadar uzanarak çalışma hayatının her alanında yer bulmaktadır. Dolayısıyla, gıda sektöründen ofis işleri, lojistik, müşteri hizmetleri ve muhasebeye kadar birçok alandaki iş ve beceri kümeleri, ileri teknolojilerin sonuçlarından etkilenecektir. Kadınlar, otomasyona duyarlı işlerde daha çok yer aldıklarından erkeklerden daha yüksek bir otomasyon riski ile karşı karşıyadırlar. Bu yüksek riskli işler, sekreterlik ve diğer büro işlerinin yanı sıra kasiyerlik ve fast-food işleri gibi ön hizmet işlerini de kapsamaktadır. Bu nedenle yüksek ücretli teknik işlerde yaşanan talep artışı, kadınları bir adım daha geride birakmaktadır. 
Rutini yüksek fiziksel görevler içeren makine operatörü, zanaat ve ticaretle ilgili mesleklerin otomasyonu, büro işlerini içeren mesleklerin otomasyonu ile karşılaştırıldığında hızlanma eğilimindedir. Buna göre, ilki erkekleri, ikincisi de kadınları içeren sınıflandırmadır. Birinci senaryoya göre erkekler, kadınlara göre daha fazla sayıda iş kaybedeceklerdir. İkinci senaryoya göre ise, çok az sayıda meslek otomatizeleştirilecek ve böylece erkekler ve kadınlar benzer düzeylerde iş kaybı yaşayacaklardır (McKinsey, 2019). Ancak çalışanlar nitelikli eğitimle edinilen becerilere sahip olmaları durumunda otomasyon riski ile önemli ölçüde mücadele edebilirler. Mevcut durum göz önünde bulundurulduğunda bu becerilerin elde edilmesinde kadınlar ancak erkeklerden daha iyi performans gösterebilmeleri durumunda cinsiyet eşitsizliğinin azalması mümkün olacaktır. Böylelikle kadınlar artan eğitim seviyeleri sayesinde, otomasyon karşısında daha az dezavantaj yaşayabilirler. Kadınlar bu durumu başarılı bir şekilde sürdürürlerse, potansiyel olarak daha üretken ve daha iyi ücretli işlere sahip olabilirler. Kadınların becerilerini geliştirmelerini sağlamak, sosyal, duygusal ve bilişsel beceri kullanımı sunan işlerde daha fazla yer bulmalarını sağlayabilir.

Teknolojinin yeteneğe olan etkisi değiştikçe, kadınlar için görünüm daha da karmaşık hale gelmektedir. Bilgisayarlar, robotlar ve yapay zekâ insanların tarihsel olarak gerçekleştirdiği görevleri yerine getirme kapasitelerini hızla geliştirmektedir. Ancak yine de robotlar, gelecekte giderek daha da değerlenecek olan belirli insan yeteneklerinin yerine geçecek kadar donanımlı olmadığını kanıtlamışlardır. Bu değişen becerilerin ve iş profillerinin cinsiyet etkileri farklıdır. Özellikle daha da önem kazanacak olan empati ve sosyal beceriler kadınlarla daha ilişkilidir. Diğer yandan yönetim, liderlik ve ileri bilişsel çaba gerektiren roller daha fazla otomasyon riski ile karşı karşıyadır. Erkekler, özellikle yönetici seviyesindeki kadınları yönetim pozisyonlarında geride bırakmaya devam etmekte, bu nedenle kendilerini astlarının karşı karşıya kaldığı daha büyük bir otomasyon riskinden korumaktadırlar. Bu tarz cinsiyet farklılıkları genellikle kadınlar veya erkekler için kalıcı olması gerekmeyen mevcut önyargılara, kalıp yargılara ve yapısal eşitsizliklere dayanmaktadır (Kinder, 2019).

Uluslararası Çalışma Örgütü (ILO) bünyesindeki Çalışma Yaşamının Geleceği Küresel Komisyonu'nun (Global Commission on the Future of Work) yayınladığ ${ }_{1}$ "Daha Parlak Bir Gelecek İçin Çalışma Yaşamı" (Work For Brighter Future) raporuna göre (2019), aynı işi yapan erkekler ve kadınların maaşları arasında \%20'lik bir fark vardır. İnsanların yeteneklerine yapılan yatırım, dijital çağın gerektirdiği yeni meslekler ve mevcut mesleklerdeki değişim göz önünde tutularak, yaşam boyu öğrenme süreçlerinin desteklenmesi, gençlerin iş yaşamına geçişlerinin ve çalışmak zorunda olan yaşlıların kendilerine uygun işlere geçişlerinin kolaylaştırılması açısından önemli bir konudur. Ayrıca çalışma hayatında cinsiyet eşitliği için dönüştürücü bir gündem oluşturma çağrısında bulunan raporda, ekonomide kadınların temsiliyetinin ve liderliğinin güçlendirilmesinin çalışma hayatının geleceği için kritik önem taşıdığı ifade edilmiştir (ILO, 2019a).

Çalışmanın geleceğinde artan esneklik türleri kadınların istihdamını artırabilir, ancak iş kalitesiyle ilgili endişeleri de beraberinde getirebilir. Dijital teknolojiler ve esnek çalışma biçimleri, cinsiyete dayalı daha dengeli kariyer yollarının geliştirilmesine ve ücret eşitsizliklerinin azaltılmasına yardımcı olabilir. Dolayısıyla yeni teknolojileri kullanarak esnek çalışma yöntemlerini teşvik etmek önemlidir. Ancak esnek çalışma biçimleriyle iş 
kalitesinin düşmemesinin sağlanması da ayrı bir önem arz etmektedir (OECD, 2017). Nitekim esnek çalışma biçimleri iş güvencesizliğini artıran biçimleriyle daha fazla uygulandığından, bunu önleyecek stratejilerin geliştirilmesi ve yasal düzenlemelerin hayata geçirilmesi öncelikli konulardandır.

\section{TEKNOLOJİK DÖNÜŞÜM KARŞISINDA KADINLAR}

Mevcut dönem ve önümüzdeki on yıl, bilim ve teknoloji alanları için hem zorluklar hem de heyecan verici fırsatlar sunmaktadır. Teknolojik yenilik, toplumun ve küresel ekonominin hemen her alanında önemli bir rol oynayacaktır. Şu anda teknolojide yeterince temsil edilmeyen kadınlar ve diğer grupların teknolojik satın alma ve tüketimi giderek daha fazla etkileyeceği muhtemeldir. Teknolojiden her anlamda yararlanan şirketler, bu sayede teknolojik pazarlara hitap etmek, çeşitli yeteneklerin perspektiflerinden faydalanmak ve teknoloji endüstrisinde lider olmak için bir adım önde olacaklardır (Ulusal Kadın ve Bilgi Teknolojileri Merkezi Raporu, 2016).

Kadınlar ve erkekler hem gelişmiş hem de gelişmekte olan ekonomilerde farklı mesleklerde yer almakta ve her biri için olası iş kaybı ve kazanımları farklı biçimlerde ortaya çıkabilmektedir. Dünya çapında kadın çalışanların \%7 ile \%24'ünün mesleki dönüşüm yaşaması beklenmektedir. Erkekler için bu oran \%8 ile \%28 arasındadır. Kadınlar teknolojik dönüşüm fırsatlarından yararlanırlarsa, mevcut istihdam paylarını koruyabilirler; aksi takdirde işgücü piyasasındaki cinsiyet eşitsizliği daha da kötüleşebilir. Kadınların bu dönüşüme başarılı bir şekilde adapte olabilmesi için yeni becerilere ihtiyaçları olacaktır. Teknoloji çağında, 40 milyon ile 160 milyon kadının 2030 yılına kadar daha yüksek vasıflı rollere sahip olması beklenmektedir (McKinsey, 2019). Kadınlar bu dönüşümü tamamlayabilirlerse, daha üretken, daha iyi ücretli işler bulabilir; ancak tamamlayamazlarsa, artan bir ücret farkıyla karşılaşabilir veya işgücü piyasasında yer alma tercihleri bundan olumsuz etkilenebilir.

Düşük ve orta ücretli işlerde çalışanların otomasyon nedeniyle işlerini kaybetme tehlikesi ile karşılaşması, kadınlar üzerinde dolaylı etkiler ortaya çıkarabilir. Düşük ve orta ücretli işler azaldıkça ücretler baskı altına girebilir. Ücretler düştüğünde kadınlar ücretli çalışma ve ücretsiz bakım arasında kendilerine yer edinme gerçeği ile karşılaşırlar. Dolayısıyla kadınlar, ücretler üzerinde aşağı yönlü bir baskı ile karşılaştıklarında işgücü piyasasını erkeklerden daha kolay terk edebilirler.

Kadınların uzun zamandır var olan engelleri, mesleki anlamda dönüşüm yaşamalarını zorlaştırabilir. Kadınlar ev ve bakım işlerine erkeklerden çok daha fazla zaman harcamaktadırlar. Kendilerini geliştirmek veya iş aramak için daha az zamanları olması onları daha az hareketli yapmaktadır. Bu nedenle kadınların dijital teknolojiye erişimleri ve FeTeMM alanlarına katılımları erkeklerden daha düşüktür (McKinsey, 2019).

'Öğrenilmiş teknolojik çaresizlik' bireyin teknolojiyi etkili bir şekilde öğrenme aracı olarak kullanmaya ve teknoloji odaklı bir toplumda kişisel üretkenlik için yetenekleriyle ilgili inançlarına odaklanan bir kavramdır (Harris, 2008). Buna göre birey, teknolojiyi kullanmada başarısız olduğunda bu başarısızlıklara dayanarak gelecekte teknolojiyi kullanmada başarısız olacağına inanmaya başlamakta ve bireyin gelecekteki performansı da olumsuz etkilenmektedir. Harris (2008) çalışmasında ataerkil bir toplumda sosyalleşen kadınların 
yaşadığ etkilendiğini savunmuştur. Yazar önceki kuşakların Amerikalı kadınları teknolojide iyi olacak şekilde sosyalleştirilmediklerini, bunu erkeklerin işi olarak gördüklerini ve bu yüzden de teknoloji rol modellerinde kadınlar için bir eksiklik oluştuğunu ifade etmiştir.

Adam ve arkadaşları (2006) kadınların BT alanındaki işgücü anlamındaki varlıklarına dair belirli stratejiler tanımlamışlardır. Bunlardan ilki BT işgücüne dahil olmamaktır. Buna göre kadınlar "yapabiliriz, istemiyoruz" yaklaşımını benimsemektedirler. İkinci bir strateji, kadınlar için zorlu olmaya devam eden bir çalışma ortamı sunan BT alanını bırakmaktır. Bu aynı zamanda bu alandaki sayısal düşüşün de (Birleşik Krallık'taki) bir göstergesi olabilir. Son olarak, BT'deki kadınların teknik beceriler kazandıklarında erkekliğe ve aslında kendi kadınlıklarına bir meydan okuma teşkil edebileceğini kabul ederek, kişinin cinsiyetini görünmez kılmaya çalışmaktır. Bu durum kısaca kadınları BT ve teknik becerilerden uzaklaşmaya eşlik edecek şekilde kişinin cinsiyet kimliğini inkâr etmeye çalışmasıdır. Bu stratejide kadınların kadın olarak gözle görülür bir şekilde öne çıkmamaları gerektiğini düşündükleri ve başarılı olmak için kayda değer bir irade gücüne ve azmine sahip olmaları gereken hâkim toplumsal düzene dair gelişmiş bir farkındalık söz konusudur.

Genel olarak FeTeMM ve bilgi teknolojileri sektörlerinde kadın temsiliyetinin düşük olmasının ve mevcut eşitsiz koşulların kadınlara yönelik ayrımcılığı ve eşitsizliği yeniden üretmesinin dışında kadınların internete ve teknolojilere erişiminin, gelişmiş ülkeler dişında erkeklere nazaran daha düşük olması, dijital dönüşümün eşit bir zeminde başlamadığını ve kadınları daha olumsuz etkileyeceğini göstermektedir (Karakaş, 2020). Teknoloji ile beraber daha yüksek düzeyde bilgisayar bilgisi ve becerisi gerektiren işlerde çalışmak hem kadınlar hem de erkekler için daha yüksek kazanç elde etmek demektir. Bilgisayar ve dijital medya ile çalışmak cinsiyetler arasındaki ücret farkını ortadan kaldırmamakta, kadınların erkeklerden daha az dijital okuryazarlığa sahip olmasından ötürü düşük kazanç elde etmelerine sebep olmaktadır. Dolayısıyla kadınlar bilgisayar ve dijital medya kullanımını gerektiren ve geleceğin teknolojisini üreten yüksek ücretli teknoloji işlerinde daha az temsil edilmektedirler (IWPR, 2019).

AB'de en çok temsil edilen 20 meslek arasından sadece 5'i cinsiyet dengeli bir işgücüne sahiptir. Erkekler, bilişim teknolojileri de dahil olmak üzere mühendislik ve teknoloji gibi alanlara hâkim iken, kadınlar eğitim ve bakım ile ilişkili alanlarda daha çok yer almaktadırlar (EIGE, 2018). Cinsiyet ayrımcllı̆̆ının devam etme sebepleri arasında; cinsiyet kalıp yargıları, dijital beceriler ve eğitim geçmişlerinde cinsiyet ayrımı, eril örgüt kültürü ve ebeveynler veya bakıcılar için iş-yaşam dengesi seçeneklerinin eksikliği gibi pek çok açıklama söz konusudur.

\section{TOPLUMSAL CINSIYYET KALIP YARGILARI VE FETEMM ALANINA ETKİSI}

Cinsiyet eşitliği sadece kadınların ve erkeklerin günlük yaşamını ve refahını değil, aynı zamanda ülke ekonomisini ve rekabet gücünü de etkileyen önemli bir bileşendir. Kadınların ve erkeklerin eğitim ve istihdamda gerçek seçimler yapmalarını engelleyen toplumsal cinsiyet stereotipleri (kalıp yargıları) ve yapısal engeller gerçek bir sosyal ve ekonomik tehdit oluşturmaktadır (EIGE, 2018). 
Kalıp yargılar, "belirli grupların üyelerinin özelliklerine, niteliklerine ve davranışlarına ilişkin inançlar" olarak tanımlanmaktadır (Carli vd., 2016). Cinsiyet ve FeTeMM ile ilgili kalıp yargılarda kimlerin FeTeMM alanlarında yer edinebileceği ve FeTeMM'de çalışmanın anlamına dair inanışlar yer almaktadır (Cheryan, 2011). Araştırmalar erkeklerin, kadınlardan daha fazla, matematik ve fen ile ilgili güçlü kalıp yargıları olduğunu göstermektedir. Bu cinsiyet kalıp yargıları çocuklar, ergenler, yetişkinler ve hatta bilim insanları arasında da yaygindir.

Carli ve arkadaşları tarafından (2016) yapılan ve başarılı bilim insanlarına dair kalıp yargılar arasındaki benzerliğin incelendiği araştırmada, erkek bilim insanları katılımcılar tarafından, lider, analitik, rekabetçi ve bağımsız (aracı) olarak görülürken, kadın bilim insanları daha nazik, sıcak, anlayışlı ve yardımsever (toplumsal) olarak görülmüşlerdir. Kadın ve erkekleri temsil eden karakteristik özelliklerin farklı olduğu gerçeğinden hareketle bu durum kadın bilim insanlarını temsil eden kalıp yargıların da farklılaştığını ortaya çıkarmıştır.

Cinsiyet kalıp yargıları, erkeklerin ve kadınların niteliklerine ilişkin genellemelerdir. Cinsiyet kalıp yargılarının hem tanımlayıcı hem de kuralcı özellikleri vardır. Tanımlayıcı ve kuralcı cinsiyet kalıp yargıları ve ürettikleri beklentiler bir kadının kariyer gelişimini olumsuz etkileyebilir. Tanımlayıcı kalıp yargılar, bir kadının nitelikleri ile geleneksel olarak erkek mesleklerinde ve örgütsel pozisyonlarda başarılı olması için gerekli olduğuna inanılan nitelikler arasında algılanan "bir uyum eksikliği" yaratması durumunda kadınların performansı hakkında olumsuz beklentiler ortaya çıkarmaktadır (Heilman, 1983). Bu noktada rol uyum teorisi ise, sosyal rol teorisi kapsamında cinsiyet rollerinin içeriğine ve davranışlardaki cinsiyet farklılıklarının önemine dayanmaktadır (Eagly vd., 2002).

Lindsay ve arkadaşları (2016) çalışmalarında kadınların bilgi ve iletişim teknolojilerine daha az ilgi duydukları ve yeterli bilgiye sahip olmadıkları bulgusunu elde etmişlerdir. Dahası, kalıp yargılar, kadınların FeTeMM'in "erkek işi” olduğunu düşünmelerine yol açmaktadır. Araştırmada, genç kadınlardan oluşan katılımcıların, eğitim programlarını seçerken bir aile kurmalarına izin veren kariyerlere odaklandıkları ve başkalarına bakma eğilimleri ya da öyle olması gerektiğine dair inançları nedeniyle sağlık ve eğitim programlarına daha fazla yöneldikleri bulunmuştur.

Diekman ve arkadaşları (2011) bazı bireylerin başkalarına hizmet etme veya onlara yardım etme gibi toplumsal hedeflere diğerlerinden daha fazla değer verebileceklerini ifade etmişlerdir. Bu durum kişilik farklılıkları ya da bu tür değerlerin daha belirgin olması ile ilişkilendirilmiştir. Ayrıca bireylerin bu hedefleri kolaylaştıran veya engelleyen faaliyetler hakkında da inançları ya da kalıp yargıları vardır. Yazarlara göre kadınların toplumla ilişkili hedeflere erkeklerden daha fazla eğilimlerinin olması ve FeTeMM kariyerlerinin toplumsal hedefleri engellediğine dair kalıp yargılar, kadınların FeTeMM kariyerlerine ilgisiz kalmalarına yol açmaktadır.

Stanford Üniversitesi tarafından yayınlanan bir rapora göre, olumsuz kalıp yargılar kadınların erkeklere kıyasla kendi yeteneklerinden şüphe etmelerine daha fazla yol açmaktadır. Buna bağlı olarak kızlar (kız çocukları ve çalışma hayatına henüz girmemiş genç kadınlar kastedilmektedir) FeTeMM kariyerlerini tercih etmemekte ya da söz konusu kariyer alanlarından ayrılmaktadırlar. Kadınlar bu kalıp yargılardan ötürü daha iyi performans 
gösterme ve meşruiyetlerini kanıtlama baskısı hissettiklerini ve erkek egemen kariyere girmenin çok zor göründüğünü düşünmektedirler (Fanelli, 2019).

Kız çocuklarının bilgisayar mühendisliği gibi alanlara girmelerine ve bu alanlarda devam etmelerine dair engelleri Cheryan ve diğerleri (2015) şu şekilde sıralamıştır: Birincisi, kızlar bilgisayar mühendisliği alanının erkekler için daha uygun olduğunu düşünen ebeveynler, öğretmenler ve diğerleri tarafından bu alanlardan uzaklaştırmaktadır. İkincisi, yetersiz temsil edilmeyle ilişkilidir, yani kadınlar bu meslek gruplarından kendilerine benzer hissettikleri insanları göremeyince bu alanlara girmek konusunda daha isteksiz olmaktadırlar. Üçüncüsü, kızlar bu alanlarda ne kadar iyi olacaklarını sistematik olarak hafife aldıklarında bu onların alana girmeye ilgilerini azaltmaktadır. Dördüncüsü, kızlar bu alanda daha fazla iş-aile çatışmasıyla karşılaşacakları beklentisinde girmektedirler. Beşincisi, bu alanlarda nitelikli kadınların erkek meslektaşlarıyla aynı fırsatları elde etmesini engelleyen bir ayrımcılık söz konusudur. Altıncısı, maskülen görülen alanlara giren kadınlar, yetkinlik ve liderlik nitelikleri sergiledikleri için sosyal ve profesyonel anlamda cezalandırılma riskiyle karşılaşmaktadırlar.

Öte yandan kız çocuklarının kendilerine ve alanın kültürüne dair kalıp yargıları, onların bu alanlardan uzaklaşmalarına ve öğrenme fırsatları ile kariyer isteklerini kısıtlamalarına yol açabilmektedir. Kız çocuklarının kendilerine dair kalıp yargıları, "kızlar erkeklerden daha az yeteneğe sahiptir" algısıdır. Alanın kültürüne dair kalıp yargılar ise, sosyal olarak izole edilmiş çalışma alanlarına ve teknoloji odaklı maskülen işlere dair kalıp yargılardır. Bu tip kalıp yargılar kadınların bilgisayar bilimleri ve mühendisliğe katılımını doğrudan etkilemektedir (Cheryan vd., 2015).

Çalışma hayatının sosyal ve kültürel inşası, kadın ve erkeklerin çocukluk döneminde başlamaktadır. Dolayısıyla mesleki kalıp yargılar okul öncesi yıllara kadar dayanmakta ve çocukların cinsiyete uygun meslek alternatiflerini ciddi bir şekilde sınırlayabilmektedir. Yeni teknolojiler yeni meslekler yarattıkça, mesleklerin cinsiyet rollerine göre toplumlarda nasıl ortaya çıtı̆̆ını ve desteklendiğini anlamak önemlidir. Erkeklerde ve gençlerde bilgisayarlara karşı daha olumlu bir tutum gözlenmektedir. Teknolojiye dair tutumlardaki cinsiyetler arasındaki bu fark, çocuklukta başlamakta ve daha sonra meslek seçimine kadar devam etmektedir (Heppner, 2013).

Önyargılar ve kalıp yargılar yeteneklerin cinsiyetini ve etnik yapısını derinden etkileyerek dünyadaki teknolojik yeniliklere katılımı sınırlandırmaktadır (Klawe vd., 2009). Pek çok FeTeMM alanı, özellikle fen ve bilgisayar bilimi gibi daha çok erkek egemen olanlar, başarı için yüksek düzeyde yetenek ve zekânın gerekli görüldüğü bir kültürü paylaşmaktadır. FeTeMM alanı hakkındaki kalıp yargılar, kadınların sahip olduğu varsayılan toplumsal özelliklerin değerini düşürürken, aynı zamanda eril kodlu özelliklere ayrıcalık tanımaktadır (Thebaud ve Charles, 2018). Eril özellikler ile FeTeMM disiplini arasındaki ilişkinin anlamı ise, erkeklerin yalnızca betimleyici bir bakış açısı ile daha "uygun" olarak algılanması değil, aynı zamanda kariyeri için daha büyük sosyal baskı ve ödülle karşılaşmalarının muhtemel olmasıdır. Diğer bir deyişle, erkekler varsayılan yeteneklerini ve ilgi alanlarını yüksek statülü bir kariyerle uyumlandırabilir ve aynı zamanda nasıl davranmaları gerektiğine dair beklentileri de karşılayabilirler. Bu nedenle bir erkek, mesleki olarak beğenilme ve saygı görme şansını artırabilir. Ancak bu ilişki bir kadın için o kadar da net değildir. Bir kadına 
yüksek statülü bir kariyer peşinde koştuğu için saygı duyulsa da bu tercih kadının ilgi alanlarına veya yeteneklerine uygun olarak algılanmayabilir. Dolayısıyla kadınlar hayranlık veya saygı kazanmayabilir, ayrımcılık veya dışlanma riskiyle karşı karşıya kalabilirler (Thebaud ve Charles, 2018).

\section{SONUÇ VE TARTIŞMA}

$\mathrm{Bu}$ makalede FeTeMM alanında kadınların konumunu tartışmak ve alandaki cinsiyet eşitsizliği durumunu kadınlar lehine desteklemek için politika önerileri geliştirmek amaçlanmıştır. Çünkü teknolojinin işgücü piyasasındaki cinsiyet boşluklarını kapatması veya genişletmesi bu konudaki politikalara ve bunların nasıl uygulandığına bağlıdır. Çalışmada teknolojik dönüşümle beraber çalışmanın geleceğinde kadınların karşılaşacağ olası durumlar değerlendirilmiştir.

Kadınların ev dışındaki ekonomik faaliyetleri, daha iyi sağlık, daha az aile içi şiddet ve toplum için de daha büyük ekonomik büyüme anlamında iyi sonuçlar yaratmaktadır (Winkler, 2016). Bununla birlikte nitelikli eğitime erişim, kadınlar için istihdama katılımı iyileştirmede çok önemlidir. Kadınların yeterli düzeyde eğitim imkânına ulaşamaması, çalışmaları durumunda daha düşük ücret almalarına ve emek yoğun sektörlerde, uzun saatler boyunca çalışmalarına neden olmaktadır (IKKV, 2019).

Çalışmanın geleceği ve mesleki dönüşüm süreci ile ilgili öngörüler büyük ölçüde farklılaşsa da teknolojik değişimin birçok meslekte işin gerçekleştirilme şekli üzerinde önemli bir etkisi olacağı konusunda ortak bir görüş vardır. Birçok teknolojik yenilik türü çok hızlı bir şekilde ilerlemektedir, ancak bu ilerlemelerin çalışma hayatına yansıma hızları tam olarak bilinmemektedir. Teknolojik yenilikler iş ve yaşam kalitesini iyileştirmek için potansiyele sahip olsa da birçok meslekte de yeni sorunlara neden olması muhtemeldir. Kadınların ve erkeklerin genellikle farklı işler yaptıkları ve kadınların ev içi bakım emeği gibi ücretsiz işlerde daha fazla sorumlulukları olduğu göz önünde bulundurulduğunda, teknolojik değişikliklerin kadınlar ve erkekler üzerinde farklı etkileri vardır ve bu anlamda politikaların cinsiyete duyarlı bir şekilde tasarlanması gerekmektedir.

Genç bir bireyin belirli bir eğitim veya mesleğe ilgi duymasını belirleyen aile, öğretmenler, diğer rol modeller gibi birçok faktör vardır. Genç kadınların FeTeMM potansiyellerini ve ilgi alanlarını tanımlamak, onları teşvik etmek, gelişmelerine yardımcı olmak ve ilgi alanlarının gelişmesi için fırsatlar sağlamak üzere aktif etkileyicilere ihtiyaç vardır. Kodlama veya robotik düşünme gibi FeTeMM uygulamalarını erken yaşta keşfetme fırsatlarına sahip olmak, sorunlara yaratıcı çözümler sunan eleştirel düşünme becerilerini kullanmayı sağlamaktadır (Climer vd., 2015).

Kadınların FeTeMM alanlarına katılımını artırmayı amaçlayan Amerikan merkezli bir sivil toplum örgütü olan WTC'ye göre teknoloji şirketlerinin toplumsal cinsiyet açısından sosyal içermeyi bir öncelik haline getirmeleri önemlidir. İçerme, bir çalışanın işyerinde başkaları tarafından kabul edilme ve aynı zamanda bireylerin katılımlarına veya katkı sağlamalarına ne ölçüde izin verildiğiyle ilgilidir. Sosyal içerme, yoksulluk ve sosyal dişlanma riski altındaki kişilerin ekonomik, sosyal ve kültürel hayata katılımları ve refah standartlarından eşit şekilde yararlanmalarını sağlayan bir süreçtir. Özellikle teknoloji temelli işlerde dışlanma riski ile karşı karşıya kalan kadınların desteklenerek kaynaklara erişiminin 
artırılması sosyal içerme açısından önemlidir. Bu sayede teknoloji şirketleri de kendileri için fırsatlar yaratmış olacaklardır (WTC, 2018).

Beşerî sermayeye yapılan yatırımların teknolojik değişim karşısında özellikle kadınlar için en büyük getirilere sahip olacağı aşikârdır. Beceriler, teknolojiden dolayı işinden edilmeye karşı en önemli korumayı sağlayacak ve kadınların yaratılan yeni iş fırsatlarından faydalanmalarını sağlayacaktır. Dar, belirli bir işe özgü beceri ve yeterliliklere olan talep azalmaktadır ve ileri bilişsel becerilere (eleştirel düşünme, problem çözme ve öğrenme çevikliği) ve sosyo-duygusal becerilere (yaratıcılık, merak ve uyumluluk) olan talep artmaktadır. Bu durum, değişen bir işyeri için beceri uyumsuzluklarını azaltmak ve yaşam boyu öğrenmenin önündeki engelleri kaldırmak için eğitim sistemlerine ve işgücü eğitimine yönelik uyum ve reformun gerekliliğini göstermektedir (IMF, 2018).

Kadınlar, büyük teknolojik risklere rağmen işin geleceği ile ilgili tartışmalar, hikâyeler ve politikalar içerisinde çoğunlukla görünmez konumdadırlar. Teknolojik değişimlerin kadınları yakından etkilediği gerçeğinden hareketle; kadınların görünür olmasının sağlanması önemlidir. İşin geleceği konusundaki tartışmalarda cinsiyet dengesizliğini ortadan kaldırarak kadınları politika öncelikleri içerisine dâhil etmek gerekmektedir. Teknolojinin kadın çalışanlar üzerindeki etkisini ele alan kamusal ve toplumsal tartışmaları yürüten politika yapıcılar ve uzmanlar arasına kadınları dâhil etmek kalıcı cinsiyet dengesizliğini ortadan kaldırmak adına önemli olabilir. Teknoloji ve otomasyona elverişli olan işlerde çalışanlarla (özellikle kadın çalışanlarla) doğrudan iletişim kurmak, onlara ses vermek, motivasyonlarını ve tercihlerini anlamak önemlidir (Kinder, 2019).

Dijital dönüşüm, kadınların işgücünde karşılaştığı bazı engelleri azaltma fırsatı sunmaktadır. Ancak bu süreç otomatik olarak gerçekleşmemekte, kadınlar bu konuda pek çok engelle karşılaşmaktadırlar. Bu durumdan kaçınmak için; FeTeMM alanlarında çalışma yapma olasılıkları daha düşük olan kadınların mühendislik, bilgisayar ve matematiksel çalışma alanlarındaki iş fırsatlarına erişimlerini kolaylaştırmak, FeTeMM'e katılımlarını teşvik etmek ve bu alanda farkındalıklarını artırmak gerekmektedir (OECD, 2017).

Politika yapıcıların, kadınların FeTeMM alanlarına girişine dair engellerin üstesinden gelmeleri için kadınlara yönelik hedefleri hızlandırmaları gerekmektedir. Söz konusu öncelikler arasında, eğitim ve mesleki dönüşüm desteğine daha fazla yatırım yapılması; daha fazla çocuk bakımı hizmeti ve güvenli ve uygun maliyetli ulaşım; kadınların mobil internete ve dijital becerilere erişimini artırmak; FeTeMM mesleklerinde ve girişimciliğinde kadınları desteklemek gibi faaliyetler gelmektedir. Yönetici pozisyonlarında kadın liderlerin sayısını ve görünürlügünü artırmak daha etkin bir kurumsal yönetim ve kadın istihdamı için olumlu etki yaratmanın yanı sıra, teknoloji alanının erkek egemen bir dünya olduğu algısını değiştirme konusunda da etkili olacaktır (Deloitte, 2018). Dolayısıyla teknoloji alanında başarılı kadın lider ve yönetici modellerini artırmak için cinsiyet kalıplarını yıkmaya ve bu sektörde daha fazla kadın istihdam edilmesine ihtiyaç vardır.

Teknoloji sektörünün geleceği için dijital eşitsizliklerin giderilmesine ve dijital yetkinliklerin geliştirilmesine odaklanmak büyük önem taşımaktadır. Teknoloji alanında çalışan kadınerkek sayılarının eşitliği ancak okul yıllarında kız öğrencilerin daha fazla teknik alanlara yöneltilmesiyle başarılabilir. Öğrencileri teknoloji ve içinde yaşadı̆̆ımız dünyayı nasıl şekillendirdiği konusunda eğitmek; teknoloji kariyerlerine erişimi artırmak, her düzeyde 
görünür rol modellerinin olması önemlidir ve de kadınların sektördeki tüm potansiyellerine ulaşmalarına yardımcı olmak gerekmektedir (PwC UK, 2017).

Hukuki, yasal ve politika stratejileri, kadınların işgücü piyasasındaki rolünü destekleyen kültürel normları ve baskıcı yapıları değiştirmede önemli bir rol oynamaktadır (Olney, 2018). Toplumsal cinsiyet farkındalığını oluşturmak için, kadınlara yönelik dezavantajı gideren, kadınlara yönelik kalıp yargıları, önyargıları ve şiddeti ele alan ve kadınların farklı sosyal konumlarını tam olarak dikkate alarak yapısal değişimi ele alan bütünsel bir görüşe ihtiyaç vardir.

\section{KAYNAKÇA}

Adam, A., Griffiths, M., Keogh, C., Moore, K., Richardson, H. \& Tattersall, A. (2006). Being an 'it'in IT: Gendered Identities in IT work. European Journal of Information Systems, 15(4), 368-378.

Aksoy, B. (2012). Bilgi Teknolojileri ve Yeni Çalışma İlişkileri, Ege Akademik Bakış, 3, pp. 401414.

Atalay, Y. ve Varol, Ç. (2016). İleri Teknoloji Sektöründe Kadın Girişimciliği: Ankara'daki Sektörel ve Mekansal Farklılaşmalar, TMMOB Şehir Plancıları Odası Planlama 2016; 26(3):181-192.

Carli, L. L., Alawa, L. Lee, Y. Zhao, B. \& Kim, E. (2016) Stereotypes About Gender and Science: Women $\neq$ Scientists, Psychology of Women Quarterly, 40(2) 244-260.

Cheryan, S. (2011). Understanding the Paradox in Math-Related Fields: Why do Some Gender Gaps Remain While Others Do Not? Sex Roles, 66. doi:10.1007/s11199-0110060-z.

Cheryan, S., Master, A. \& Meltzoff, A. N. (2015). Cultural Stereotypes as Gatekeepers: Increasing Girls' Interest in Computer Science and Engineering by Diversifying Stereotypes. Frontiers in Psychology, 6, 49.

Climer, N., Ratcliff, T. H. \& Koon, P. W. (2015). How To Attract More Women into STEM Careers, Automation Federation.

Cohen, P. N. (2004). The Gender Division of Labor: "Keeping House" and Occupational Segregation in the United States. Gender and Society, 18(2), 239-252.

Deloitte, Türkiye ve Türkiye Bilişim Sanayicileri Derneği (TÜBİSAD). Teknoloji Sektöründe Kadın Araştırma Raporu, Eylül 2018.

Diekman, A. B., Clark, E. K., Johnston, A. M., Brown, E. R. \& Steinberg, M. (2011). Malleability in Communal Goals and Beliefs Influences Attraction to Stem Careers: Evidence for a Goal Congruity Perspective. Journal Of Personality and Social Psychology, 101(5), 902.

Eagly, A. E. \& Karau, S. J. (2002). Role Congruity Theory of Prejudice Toward Female Leaders, Psychological Review, 109(3), 573-598. 
Ecevit Satı, Z. ve Oktay Yılmaz, B. (2019). Endüstri 4.0 Ortamında Değişen İş ve Mesleklerin Türkiye'de Kadın İstihdamına Etkileri. Strategic Public Management Journal, 6(11), 5476.

European Institute for Gender Equality (EIGE), Women and men in ICT: a Chance For Better Work-Life Balance Research Note. 2018.

Fanelli, D. (2019). Beating Gender Stereotypes: Women in STEM. HR Technoologist Articles. URL: https://www.hrtechnologist.com/articles/diversity/beating-gender-stereotypeswomen-in-stem/ (Erişim: 25.04.2021)

Harris, J. E. (2008). "The Impact Of Gender Socialızation On Women's Learned Technological Helplessness And Its Andragogical Implicatıons" (2008). Dissertations.

Heilman, M. E. (1983). Sex Bias in Work Settings: The Lack Of Fit Model. In Staw, B., \& Cummings, L. Eds. Research in Organizational Behavior (Vol.5). Greenwich.

Heppner, M. J. (2013). Women, Men, and Work: The Long Road to Gender Equity, Career Development and Counseling: Putting Theory and Research to Work, Second Edition, Section Two, Chapter 7, pp. 187-214.

Howcroft D. \& Rubery J. (2019). 'Bias in, Bias Out': Gender Equality and The Future of Work Debate, Labour \& Industry, A Journal Of The Social and Economic Relations of Work, 29:2, 213-227.

IMF Staff Discussion Note (2018). Gender, Technology and the Future of Work. Fiscal Affairs and Human Resources Departments Discussion Notes.

İktisadi Kalkınma Vakfı (İKV) Değerlendirme Notu, AB Katılım Sürecindeki Türkiye'nin Kadın İstihdamı Karnesi Ocak 2019.

Kadın Emeği ve İstihdamı Girişimi (KEİG), Çalışma Yaşamında Kadınlar Forumu Raporu, 2015.

Karakaş, Ö. (2020). Dijitalleşme ve Kadın Emeği, Terrabayt Online Dergi, URL: https://terrabayt.com/yasam/dijitallesme-ve-kadin-emegi/ (Erişim: 25.04.2021)

Kinder, M. (2019) The Future of Work for Women: Technology, Automation \& the Overlooked Workforce URL: https://www.newamerica.org/work-workerstechnology/shiftlabs/blog/future-work-women/ (Erişim: 25.04.2021)

Klawe, M., Whitney, T. \& Simard, C. (2009). Women in Computing, Take 2.

Lindsay, S., Taylor, A., Woodward, B. \& Milligan, M. (2016). A “Male Thıng": Why College Women Are Not Choosing Stem Majors. Issues in Information Systems, 17(3).

McKinsey Global Institute, The Future of Women at Work: Transitions in the age of automation, June 2019.

O'Donnell, C. (2019). Charting a Course for Success: America's Strategy for STEM Education. URL: https://ssec.si.edu/stemvisions-blog/charting-course-successamericas-strategystem-education (Erişim: 24.04.2021) 
OECD (2017). Policy Brief On The Future Of Work Going Digital: The Future of Work for Women.

Olney, S. (2018) A Better Future for Women at Work, University of Oxford Human Rights Hub Journal.

Ortiz-Ospina, E., Tzvetkova, S. \& Roser, M. (2018). Female Labor Supply, Our World Data, URL: https://ourworldindata.org/female-labor-supply (Erişim: 29.04.2021)

Öktem Özgür, A. ve Seçer, S. (2017). Çalışma Yaşamında Bilgi ve İletişim Teknolojileri Bağlamında Cinsiyete Dayalı Ayrımcılık Algıları: “İnsan Kaynakları Yöneticileri ile Nitel Bir Araştırma". İş, Güç, Endüstri ilişkileri ve Insan Kaynakları Dergisi, 19(3), 57-94.

Özçatal, E. Ö. (2011). Ataerkillik, Toplumsal Cinsiyet ve Kadının Çalışma Yaşamına Katılımı. Çankırı Karatekin Üniversitesi İktisadi ve İdari Bilimler Fakültesi Dergisi. 1(1), 21-39.

PwC Türkiye, (2020). Çalışma Hayatında Kadınlar Endeksi 2020, Teknoloji Devriminin Yarattığ Firsatlar ve Zorluklar: WomenInwork.

PwC UK (2017). Women in Tech: Time To Close The Gender Gap Research Report.

Richter, F. (2020). Female Workers in the Tech Industry, Gafam: Women Still Underrepresented in Tech. URL: https://www.statista.com/chart/4467/femaleemployees-at-tech-companies/ (Erişim: 29.04.2021)

Savc1, İ. (1999). Toplumsal Cinsiyet ve Teknoloji. Ankara Üniversitesi SBF Dergisi, Cilt 54, Sayı 01.

Taş, B ve Bozkurt, E. (2019). Türkiye'de STEM Alanındaki Toplumsal Cinsiyet Eşitsizlikleri Araştırma ve İzleme Raporu. Etkiniz AB Programı ve Uçan Süpürge Kadın İletişim ve Araştırma Derneği Raporu.

The Institute for Women's Policy Research (IWPR). (2019). Women, Automation, and the Future of Work.

Thebaud, S. \& Charles, M. (2018). Segregation, Stereotypes and STEM, Social Sciences Journal, 7,111 .

Toksöz, G. ve Memiş, E. (2018). İstihdamda Toplumsal Cinsiyet Eşitliği Haritalama ve İzleme Çalışması. CEID Yayınları 5. ISBN: 978-605-64847-4-2.

Ulusal Kadın ve Bilgi Teknolojileri Merkezi Raporu (2016). Women in Tech: The Facts. National Center for Women \& Information Technology (NCWIT). By Ashcraft, C.,

McLain, B. ve Eger, E. URL: https://www.ncwit.org./ womenintech_facts_fullreport_05132016.pdf (Erişim: 29.04.2021)

Uluslararası Çalışma Örgütü- International Labor Office (ILO). (2019a) Çalışma Yaşamının Geleceği Küresel Komisyonu, (Global Commission on the Future of Work) 'Daha Parlak Bir Gelecek İçin Çalışma Yaşamı' (Work For Brighter Future) Raporu. URL: https://medium.com/platformkoop/\%C3\%A7al\%C4\%B1\%C5\%9Fmahayat $\% C 4 \% B 1 n \%$ C4\%B1n-gelece\%C4\%9Fi-afdd361cdd91 (Erişim: 29.04.2021) 
Uluslararası Çalışma Örgütü- International Labor Office (ILO). (2019b). The Social Construction Of Migrant Care Work, At The Intersection Of Care, Migration And Gender. King-Dejardin, A. ILO publications.

Winkler, A. E. (2016). Women's Labor Force Participation. IZA World of Labor, ISSN 20549571, Institute for the Study of Labor (IZA), Bonn, Iss. 289.

Women Tech Council (WTC). (2018). The Gender Gap in Tech, How to Fix it.

World Economic Forum (WEF). The Future of Jobs: Employment, Skills and Workforce Strategy for the Fourth Industrial Revolution, World Economic Forum, Cologny, Switzerland, 2016.

2018 Teknolojide Kadın Endeksi/Honeypot URL: https:/www.honeypot.io/women-in-tech2018/gbp/ (Erişim: 01.05.2021)

2019 TÜİK İşü̈ü İstatistikleri (sayı:33784, yayınlanma tarihi 20.03.2020). 